\title{
Autologus normovolemic and hypervolemic hemodilution during surgery using $6 \%$ dextran 70 and lactated ringer solution: impact on mean arterial pressure, heart rate, hemoglobin and hematocrite (A preliminary study)
}

\author{
Ruswan Dachlan, Kristanto, Eko Suprayogi
}

\begin{abstract}
Abstrak
Hemodilusi normovolemik autologus (ANH) adalah salah satu cara untuk menghemat darah donor (homologus). Penyadapan darah pasien (plebotomi) dilakukan setelah induksi anestesia dan pada waktu bersamaan diberikan cairan koloid atau kristaloid. Darah ini dapat diberikan lagi setelah prosedur utama bedah selesai. Dengan metoda ini penurunan hemoglobin (Hb) karena perdarahan pada bedah mayor dapat diminimalkan dan sekaligus hematokrit (Ht) dapat disesuaikan. Akan tetapi, karena ketidak praktisannya dalam aplikasi klinis, digunakan metoda hemodilusi lain yang lebih mudah, yaitu hemodilusi hipervolemik (HHD) dengan menggunakan larutan $6 \%$ dextran 70 dan Ringer laktat, cairan diberikan sebelum pembedahan dimulai tanpa penyadapan darah. Tujuan dari studi acak komparatif ini adalah untuk mengetahui efek-efek dari kedua metoda hemodilusi (ANH dan HHD) terhadap tekanan arteri ratarata (MAP), laju jantung (HR), hemoglobin $(\mathrm{Hb})$ dan hematokrit $(\mathrm{Ht})$ pada pasien yang dianestesi untuk bedah mayor. Empatbelas (14) wanita yang memenuhi kriteria inklusi dan eksklusi dibagi dalam 2 kelompok. Tujuh (7) wanita menerima metoda ANH dan tujuh (7) wanita menerima metoda HHD. Ternyata terdapat perbedaan yang bermakna $(P<0.05)$ pada MAP dan Ht setelah 1 menit pasca

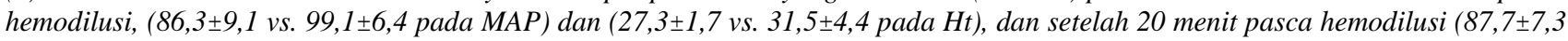

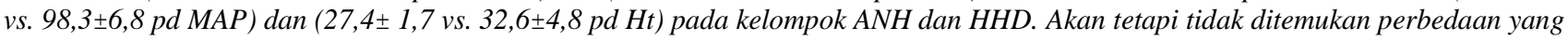
berarti pada HR dan Hb dikedua waktu pencatatan tersebut di atas. Tidak ada perbadaan berarti pada keempat parameter yang diuji setelah 120 menit pasca hemodilusi. Dapat disimpulkan bahwa kedua metoda dapat dipergunakan dalam aplikasi klinis, meskipun studi-studi lanjutan masih diperlukan. (Med J Indones 2006; 15:246-50)
\end{abstract}

\begin{abstract}
Autologous normovolemic hemodilution (ANH) is one of the methods to conserve blood donor (homologous). The decrease in hemoglobin $\mathrm{Hb}$ ) due to bleeding in major surgery will be minimized and the hematocrite (Hct) will be adjusted accordingly by this method. However, due to its impractical clinical application, another simpler hemodilution method is used, i.e. hypervolemic hemodilution (HHD), using 6\% dextran 70 and lactated Ringer solutions. The aim of this randomized comparative study was to investigate the impacts of both hemodilution methods $(A N H$ and $H H D)$ on mean arterial pressure $(M A P)$, heart rate $(H R)$, hemoglobin $(H b)$ and hematocrite (Hct) in anesthetized patients undergoing major surgery. Fourteen (14) women fulfilling the inclusion and exclusion criteria were divided into 2 groups. Seven (7) women received ANH and seven (7) women received HHD method. There were significant statistical differences $(P<0.05)$ between $A N H$ and $H H D$

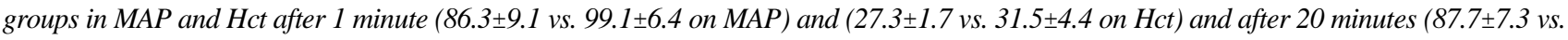
$98.3 \pm 6.8$ on MAP) and ( $27.4 \pm 1.7 \mathrm{vs.} 3.6 \pm 4.8$ on Hct) post-hemodilution respectively. There was no difference in HR and Hb. No statistical difference between the four parameters tested after 120 minutes post-hemodilution. It may be concluded that both methods worth to be used in clinical setting although further studies are required. (Med J Indones 2006; 15:246-50)
\end{abstract}

Keyword: Acute normovolenic hemodilution, acute hypervolemic hemodilution, dextran 70, lactated ringer solution, microsirculation

Autologous Normovolenic Hemodilution (ANH) has been known for years to conserve blood in major surgery. Its benefits are firstly to improve micro-

Departement of Anesthesiology and Intensive Care Unit, Faculty of Medicine, Univesity of Indonesia/Dr. Cipto Mangunkusumo Hospital, Jakarta, Indonesia circulation oxygenation and secondly to conserve red blood cells, platelets and coagulation factors. The decrease in hemoglobin $(\mathrm{Hb})$ will be minimized, adjusting to the reduced hematocrite (Hct) due to hemodilution. ${ }^{1,2,3}$ Autologous normovolemic hemodilution (ANH) is costly and impractical in clinical application, as blood has to be withdrawn (phlebotomy) and at the same time has to be replaced with colloid or crystalloid solution. ${ }^{4}$ 
As an alternative procedure, there is another hemodilution method called hypervolemic hemodilution (HHD) where proper solutions should be infused before a major surgery is undertaken. Trouwborst et $\mathrm{al}^{5}$ had shown that the need of blood transfusion in 16 of their patients who were treated with acute hypervolemic hemodilution using 6\% dextran 70 and lactated Ringer solution (1:1 proportion) was reduced without any significant difference in the red blood cell value provided that the bleeding was less than $20 \%$ of the blood volume.

This study aimed to investigate which method (ANH or HHD) would provide minimal influence to hemodynamic parameter, i.e. mean arterial pressure (MAP) and heart rate (HR), and to $\mathrm{Hb}$ and Hct.

\section{METHODS}

Approval from the Ethics Committee was obtained before the study started, and all study population had given their signed informed consent. Inclusion criteria were women who were scheduled for major surgery (Laparotomy, Miles' Operation, or Hysterectomy), with ASA 1-2, age less than 50 years old, and normal weight and height proportion. Exclusion criteria were subjects with liver or kidney disturbances, or cardiovascular, neurological, or respiratory disease. The subjects were randomly allocated to receive ANH or HHD in the 2 pairs which were scheduled for Laparotomy, 2 pairs and for Miles' operation, and 3 pairs for radical hysterectomy.

All women received general anesthesia with controlled ventilation. They were premedicated with $0.1 \mathrm{mg} / \mathrm{kg}$ BW of Dehydrobenzperidol and $1 \mathrm{mg} / \mathrm{kg}$ BW of Pethidin intramuscularly/intravenously 30/5 minutes before induction of anesthesia. General anesthesia was induced by $5 \mathrm{mg} / \mathrm{kg}$ BW of Pentobarbital and intubation was facilitated by $2 \mathrm{mg} / \mathrm{kg}$ BW of Succinyl Choline. General anesthesia was maintained with $\mathrm{N}_{2} \mathrm{O}$ and $\mathrm{O}_{2}(2: 1)$ and Enflurane (up to 2 volume \%) with Pavulon as the muscle relaxant. Before the induction, all parameters investigated were recorded.

In the ANH group, after intubation but before surgery begun, blood was withdrawn via a $16 \mathrm{G}$ intravenous catheter from large peripheral vein and collected in a blood bag. The amount of the blood withdrawn was replaced by Lactated Ringer Solution.

In the HHD group, after intubation but before surgery begun, $15 \mathrm{mg} / \mathrm{kg} \mathrm{BW}$ of $6 \%$ dextran 70 and lactated
Ringer solutions were given with the rate of $50 \mathrm{ml} /$ minute. Homologous blood transfusion might be given as necessary and recorded.

All parameters investigated were recorded at 1,20 and 120 minutes after hemodilution. The results of the study were tabulated and means \pm SD were calculated using SPSS (Statistical Package for the social science) for Windows. The average MAP, HR, Hb and Hct in the 2 groups were compared by independent t-test method, but the variables which did not follow normal distribution were tested by MANN - WHITNEY method.

\section{RESULTS}

Fourteen women were recruited and divided into 2 groups with regard to the type of the surgery. The patients demographic data did not show any statistical difference between the two groups (Table 1).

There was also no statistical difference between the two groups with regard to the parameters investigated before induction of anesthesia (Table 2).

In the HHD group, no significant difference was seen on MAP and HR between the specific time measurements and preinduction. However, $\mathrm{Hb}$ showed a significant decrease during those times, followed by Hct except on 20 minutes post hemodilution $(P=0.083)$ (Table 2$)$.

In general, there was a significant decrease compared to the pre-induction value on parameters measured in the ANH group except for HR which showed a significant increase at 20 and 120 minutes post hemodilution compared to the pre-induction value. No significant increase on HR was shown at 1 minute post hemodilution (Table 2).

Intra-operative bleeding between the two groups showed no significant difference, either for the first 120 minutes $(P=0.151)$ or after the surgeries were over $(P=0.183)$ (Table 3).

The average amount of blood transfused during the first 120 minutes period was $485.714 \mathrm{cc}$ homologous blood for all 7 patients of the HHD group (Table 4). The average amount of blood transfused at the same period in the ANH group was $482.857 \mathrm{cc}$ (Table 5). There was no significant difference between the two groups. However only 6 women in the ANH group received autologous blood. The other one got additional $380 \mathrm{cc}$ homologous blood due to surgical complication. 
Table 1. Patients' distribution based on sociodemographic character and type of surgery

\begin{tabular}{clccc}
\hline Type of data & \multicolumn{1}{c}{ Variables } & HHD $(\mathrm{n}=7)$ & ANH $(\mathrm{n}=7)$ & $P$ \\
\hline \multirow{2}{*}{ Socio demography } & Age (mean \pm SD) & $43.7 \pm 1.2$ & $42.3 \pm 4.7$ & 0.774 \\
& Weight (mean \pm SD) & $51.3 \pm 11$ & $43.2 \pm 9.6$ & 0.263 \\
& Height (mean \pm SD) & $153.4 \pm 4$ & $151.4 \pm 5.1$ & 0.430 \\
Type of surgery & Laparotomy (n) & 2 & 2 & - \\
& Milles procedure (n) & 2 & 2 & - \\
& Radical Hysterectomy (n) & 3 & 3 & - \\
\hline
\end{tabular}

HHD $=$ hypervolemic hemodilution

$\mathrm{ANH}=$ autologous normovolemic hemodilatation

Table 2. Variables measured during specific time in both groups

\begin{tabular}{|c|c|c|c|c|c|c|c|c|}
\hline \multirow[t]{2}{*}{ Variable } & \multirow[t]{2}{*}{ Groups } & \multirow{2}{*}{$\begin{array}{c}\text { Pre Induction } \\
x \underline{x} \mathrm{sd}\end{array}$} & \multicolumn{2}{|c|}{1 minute post hemodilution } & \multicolumn{2}{|c|}{$\begin{array}{l}20 \text { minutes post } \\
\text { hemodilution }\end{array}$} & \multicolumn{2}{|c|}{$\begin{array}{l}120 \text { minutes post } \\
\text { hemodilution }\end{array}$} \\
\hline & & & $x \pm s d$ & $P^{*}$ & $x \pm s d$ & $P^{*}$ & $x \pm s d$ & $P^{*}$ \\
\hline \multirow[t]{3}{*}{ MAP } & HHD & $94.3 \pm 6.9$ & $99.1 \pm 6.4$ & 0.236 & $98.3 \pm 6.8$ & 0.383 & $87.0 \pm 7.8$ & 0,155 \\
\hline & $\mathrm{ANH}$ & $90.1 \pm 7.4$ & $86.3 \pm 9.1$ & 0.043 & $87.7 \pm 7.3$ & 0.173 & $83.7 \pm 6.0$ & 0.004 \\
\hline & $P$ & 0.300 & 0.010 & & 0.016 & & 0.344 & \\
\hline \multirow[t]{3}{*}{ HR } & HHD & $90.1 \pm 19.7$ & $83.4 \pm 8.2$ & 0.310 & $84.1 \pm 6.4$ & 0.354 & $84.3 \pm 11.6$ & 0.398 \\
\hline & $\mathrm{ANH}$ & $81.1 \pm 2.0$ & $82.6 \pm 2.7$ & 0.328 & $86.7 \pm 4.5$ & 0.019 & $89.7 \pm 5.0$ & 0.002 \\
\hline & $P$ & 0.273 & 0.801 & & 0.400 & & 0.276 & \\
\hline \multirow[t]{3}{*}{$\mathrm{Hb}$} & HHD & $12.6 \pm 1.8$ & $11.1 \pm 1.7$ & 0.000 & $11.4 \pm 1.8$ & 0.014 & $10.6 \pm 1.6$ & 0.004 \\
\hline & ANH & $11.5 \pm 0.4$ & $9.7 \pm 0.3$ & 0.001 & $9.8 \pm 0.7$ & 0.001 & $9.8 \pm 0.6$ & 0.003 \\
\hline & $P$ & 0.167 & 0.065 & & 0.052 & & 0.273 & \\
\hline \multirow[t]{3}{*}{ Hct } & HHD & $35.4+4.1$ & $31.5 \pm 4.4$ & 0.003 & $32.6 \pm 4.8$ & 0.083 & $29.8 \pm 4.6$ & 0.012 \\
\hline & ANH & $31.8 \pm 1.6$ & $27.3 \pm 1.7$ & 0.003 & $27.4 \pm 1.7$ & 0.001 & $28.4 \pm 1.1$ & 0.011 \\
\hline & $P$ & 0.064 & 0.048 & & 0.019 & & $0.4 \overline{7} 1$ & \\
\hline
\end{tabular}

MAP : mean arterial pressure, $\mathrm{HR}$ : heart rate, $\mathrm{Hb}$ : haemoglobin, $\mathrm{Hct}:$ hematocrite, $P^{*}$ : compared to pre induction

Table 3. Intra-operative bleeding at the first 20 minutes and after the surgeries were over

\begin{tabular}{cccccc}
\hline \multirow{2}{*}{ No. } & \multirow{2}{*}{ Grouping } & \multicolumn{2}{c}{ The first 120 minute } & \multicolumn{2}{c}{ The total amount of bleding } \\
\cline { 3 - 6 } & & mean \pm SD & $P$ & mean \pm SD & $P$ \\
\hline 1. & HHD & $942.86 \pm 214.92$ & 0.151 & $1128.57 \pm 482.06$ & 0.183 \\
2. & ANH & $757.14 \pm 257.05$ & & $828.57 \pm 287.07$ & \\
\hline
\end{tabular}

Table 4. The average amount of transfusion at the first 120 minutes in the HHD group

\begin{tabular}{cccccc}
\hline No & Transfusion & Value $(\mathbf{c c})$ & Frequency & Percentage & Mean \\
\hline 1. & Autologous & - & - & - & - \\
2. & Homologous & 220 & 1 & 14.3 & \\
& & 400 & 1 & 28.6 & \\
& 450 & 1 & 14.3 & 485.714 \\
& 620 & 1 & 14.3 & \\
& 630 & 1 & 14.3 & \\
\hline
\end{tabular}


Table 5. The average amount of transfusion at the first 120 minutes in the ANH group

\begin{tabular}{cccccc}
\hline No & Transfusion & $\begin{array}{c}\text { Amount } \\
(\mathbf{c c})\end{array}$ & Frequency & Percentage & Mean \\
\hline 1. & Autologous & 300 & 2 & 28.6 & - \\
& & 400 & 1 & 14.3 & \\
& & 500 & 4 & 57.1 & \\
2. & Homologous & 380 & 1 & 100 & 482.857 \\
\hline
\end{tabular}

There was significant difference on MAP and Hct between ANH and HHD groups at 1 minute posthemodilution which was maintained until 20 minutes after post-hemodilution. However, these difference become insignificant after 120 minutes post-hemodilution (Table 2).

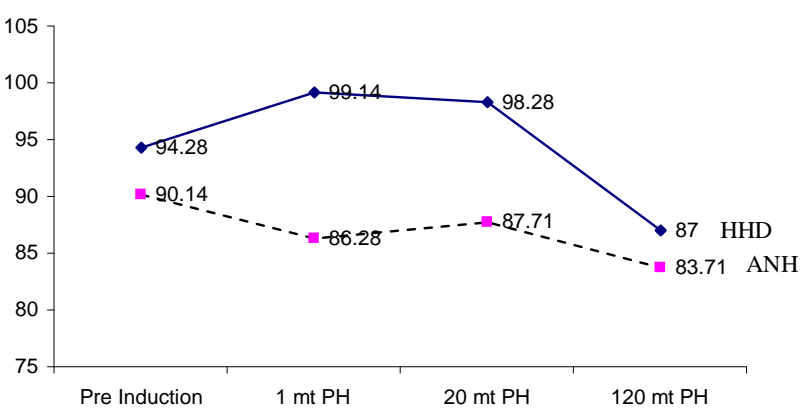

Figure1. Mean arterial pressure of the two groups $(P<0.05)$

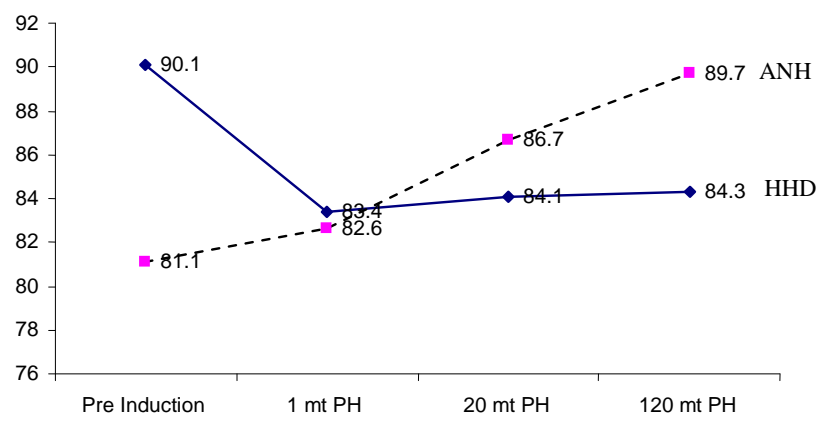

Figure 2. Heart rate of the two groups

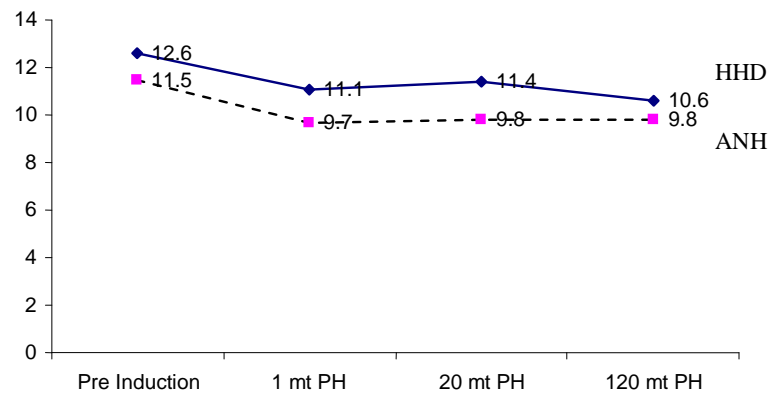

Figure 3. Hemoglobin of the two groups

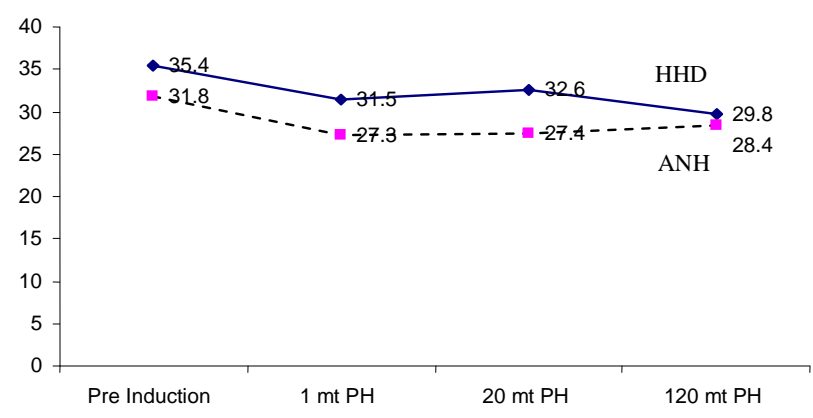

Figure 4. Hematocrite of the two groups

\section{DISCUSSION}

There was no significant difference of MAP in the ANH group observed after 1 and 20 minutes posthemodilution (Table 2). The significant decrease of MAP at 120 minutes might be due to several factors, i.e. $80 \%$ of the lactated Ringer solution infused had been absorbed by the interstitial tissue and the ongoing intra-operative bleeding which decreased the heart's pre-load. Enflurane might reduce myocard contractivity, thus decreasing stroke volume leading to reduced cardiac output. Enflurane might also reduce systemic vascular resistance. The above factors at last decreased blood pressure. ${ }^{6}$

The same results were also observed in the HHD group, although no significant difference was seen $(P=0.155)$. However, if both groups were compared, significant differences were only seen at 1 and 20 minutes posthemodilution and no difference at 120 minutes posthemodilution (Table 2). It is known that hemodilution will reduce blood viscosity, which in turn will increase venous return. ${ }^{7}$ 
The increasing tendency of MAP after 1 and 20 minutes in HHD group (although it was not significant) was due to preload volume addition. However, due to the effects of anesthesia, this increases were not significant.

The decreasing tendency of MAP after 1 and 20 minutes in the ANH group (although it was also not significant) was due to the decrease in blood viscosity, the effects of anesthesia and the decrease in arterial oxygen content. The latter in turn would increase cardiac output to maintain oxygen delivery. Thus for the ANH group, the cardiovascular response depend on the rate of hemodilution, blood volume circulation, the type of solution used to replace blood volume and the capability of compensation (defense) mechanism. The graph of MAP of the two groups is shown in figure 1 .

Heart rate is an SA node intrinsic function (spontaneous depolarization) which was influenced by autonomic function, humoral and local factors. Normal heart rate is $118-(0.57 \mathrm{x}$ age $)$ times/minute. Generally, heart rate is accelerated by sympathetic action and decelerated by vagus stimulus. ${ }^{8}$ Distinct effect was observed in experimental dog which was given pentobarbital, i.e. the acceleration of heart beat due to vagolytic effect. ${ }^{9,10}$ However, different study in human showed no distinct effect. $^{11}$

The tendency of decreasing HR (although not significant) in the HHD group might be due to stimulation reflex of baroreceptor in Carotid sinus and arcus aortae as the result of the increasing cardiac output. ${ }^{12}$ The tendency of increasing HR (although not significant) in the ANH group might be due to the cardiac output response which tended to decrease this condition, and in turn stimulated the baroreceptor to increase the heart rate, as Nicolas as cited by Morgan et $\mathrm{al}^{13}$ showed the same results. The graph of the two groups is shown in figure 2 .

It has been well known that hemodilution may decrease the values of $\mathrm{Hb}$ and $\mathrm{Hct}^{3,14}$ Each group in this study also showed a significant reduction in $\mathrm{Hb}$ and Hct values. There was a significant difference in Hct value between the two groups at 1 and 20 minutes post hemodilution, but no difference was shown at 120 minutes after hemodilution. Although there is no standard of hemodilution rate, the decrease in Hct from normal value $(40 \%)$ to the value between 25 $35 \%$ is considered as medium hemodilution and if the Hct value reaches $<20 \%$ it belonged to high hemo- dilution ${ }^{4,14}$ Thus this study showed medium hemodilution. The decrease in $\mathrm{Hb}$ value will, of course, cause the decrease in arterial oxygen content. However, this will be compensated by the increasing oxygen extraction ratio (EO2). ${ }^{4,11}$ By using ANH method we could significantly reduce the need of homologous blood transfusion. However, this method is time consuming, costly and impractical in clinical application.

It is concluded from this study that both methods could be used in clinical setting. Further studies with larger study population, broader socio-demographic variables, broader types of surgery and more variables of observation i.e. central venous pressure, arterial blood gas analyses etc. are required.

\section{REFERENCES}

1. Myhore BA. The first recorded blood transfusion. Transfusion 1990; 330:58.

2. Grant FC. Autotransfusion. American Surgery 1961; 74:253.

3. Lee CY. Autologous blood transfusion. Manual of anesthesia for medical officers. New York: McGraw Hill; 1996.

4. Crystal GJ, Salem MR, editors. Acute normovolemic hemodilution. Blood conservation in the surgical patient. Philadelphia: Williams and Wilkins; 1996.

5. Trowborst A, van Wearbens E.C, van Daele M. Acute hypervolemic hemodilution to avoid blood transfusion during major surgery. The Lancet 1990; 336:1295-7.

6. Morgan GE, Mikhail MS, Murray MJ. Inhalation anesthetics. In: Morgan GE, Mikhail MS, Murray MJ, editors. Clinical anaesthesiology. New York: McGraw Hill; 1996. p.109-27.

7. Guyton AC, Richardson TQ. Effect of hematocrite on venous return. Circulation 1961;9:157-64.

8. Atkinson RS, Mikhail MS, Murray MJ, editors. Sysnopsis of anaesthesia. $11^{\text {th }}$ ed. Oxford: Butterworth Heinemann; 1993.

9. Ho IK, Harris RA. Mechanism of action of barbiturates. An Rev pharmacotoxycol 1981;21:83-111.

10. Bruder N, Cohen B, Pellissier D, Francois G. The effect of hemodilution on COFV in anesthetized patients. Anaest analg 1998;86:320-4.

11. Spahn DR, Leone BJ, Reves JG, Pasch T. Physiology of acute isovolemic hemodilution. Anaest analg 1994; 78: 1000-21.

12. Cain SM. Oxygen delivery and uptake in dogs during anemia and hypoxia. J appl physiol 1997;42:228-34.

13. Morgan GE, Mikhail MS, Murray MJ. Fluid management and transfusion. In: Morgan GE, Mikhail MS, Murray MJ, editors. Clinical anesthesiology. New York: McGraw Hill; 1996.p.543-58.

14. Stehling L. Acute normovolemic hemodilution. In: Miller RD, editor. Anaesthesia. New York: Churchill Livingstone; 1981.p.1651-60. 